\title{
Unfolding farm practices: Working toward sustainable food production in the Netherlands and Spain
}

\author{
Paul Swagemakers, ${ }^{\mathrm{a}, \mathrm{b},{ }^{*}}$ M. Dolores Domínguez García, ${ }^{\mathrm{a}, \mathrm{b}}$ Xavier Simón Fernández, ${ }^{\mathrm{a}}$ Johannes S. C. Wiskerke ${ }^{\mathrm{b}}$
}

Submitted 25 April 2011 / Accepted 2 August 2011 / Published online 7 February 2012

Citation: Swagemakers, P., Domínguez García, M. D., Simón Fernández, X., Wiskerke, J. S. C. (2012). Unfolding farm practices: Working towards sustainable food production in the Netherlands and Spain. Journal of Agriculture, Food Systems, and Community Development, 2(2), 129-145. http://dx.doi.org/10.5304/jafscd.2012.022.001

Copyright (C) 2012 by New Leaf Associates, Inc.

\begin{abstract}
The modernization of agriculture has caused and continues to cause an increasing disconnection between farming, nature, and society, which has also created a series of social, economic, and ecological crises in the food chain. Case study research of farmers responding to this situation can show us what changes are required to encourage a reconnection between farming, nature, and society. This paper provides ethnographic case study research of two farms: one situated in a productive polder in the Netherlands, and the other in a disadvantaged mountainous area in Galicia, Spain. They both employ "novelty production," farmer-

a Grupo de Investigación en Economía Ecológica y Agroecología, Universidad de Vigo, Ciencias Económicas y

LADE, Lagoas Marcosende s/n 36310 Vigo, España.

b Rural Sociology Group, Wageningen University, P.O. Box 8130, NL-6700 EW Wageningen, the Netherlands.

* Corresponding author: Paul Swagemakers, +34662038696 /

+31618883568 / +34986814005; paul.swagemakers@uvigo.es
\end{abstract}

driven adaptations to the farm, seen as a socioecological system. These novelties change the input-output relations on farms and result in adaptations in different farming domains (technical, economic, and socio-organizational), which we see as "unfolding" farming practices. This paper examines how these farmers have sustained and improved the socio-ecological performance of their farms and how these changes have led to a shift in the farm as a socio-ecological system and changed the configuration and boundaries of the farms. In conclusion we look at prospects for this approach being supported at a wider level.

\section{Keywords}

case study research, farming, food production, novelties, novelty production, farm labor

\section{Introduction}

The modernization of agricultural food production is leading the contemporary globalized food system towards a social, economic and ecological crisis. The suggested responses to this crisis follow two 
opposing pathways or paradigms: the agroindustrial and the territorial agri-food paradigm (Lang \& Heasman, 2004; Marsden, 2003; Sonnino \& Marsden, 2006; van der Ploeg, 2003, 2006; Wiskerke, 2009). These paradigms adopt very different perspectives over a number of key issues. The former sees processes of change as driven by externally designed and radical system innovations, whereas the later sees change as driven by incremental, gradually unfolding, promising practices that are adapted to and optimize regional potentials. The agro-industrial approach favors the application of innovative industrial technologies provided by the expert system, whereas the territorial agri-food paradigm stresses the importance of skill-oriented technologies based on local knowledge. Finally, they have different views on interactions with the environment, with the former in favor of altering the environment to accommodate a large-scale production system, and the later seeking to create a balance between the environment and the current production system and its further evolution on the basis of terroir (see Barham, 2003).

We argue in this paper that sustainable food production needs to be rooted firmly in the regional context. The territorial agri-food paradigm aims to reembed food production within, and upon, the qualities and distinctive features of a region (Wiskerke, van Huylenbroeck, \& Kirwan, in press). Yet this approach does not receive much attention in the international debate on the future of agriculture and the sustainability of food supplies. Despite increasing interest in recent years (see for example the report of the United Nation's Special Rapporteur Olivier De Schutter on the potential of agro-ecology (United Nations, 2010)), the mechanisms for fostering these reconnections between farming, nature, and society have not been adequately explored or documented.

In response to this shortcoming, this article provides a comparative ethnographic approach on how the socio-ecological performance of farms can be improved through a process of adaptation, which we refer to as "unfolding" and explain as a series of "novelties": small adjustments done on the farm that result in a shift of farm boundaries (Swagemakers, 2002; van der Ploeg et al., 2004; Ventura \& Milone, 2004). ${ }^{1}$ We begin by drawing a conceptual framework that describes this process of unfolding farming, in which we distinguish system innovation generated by farmers from the one provided by the expert system. Farmer-driven novelty production differs in nature from innovations provided by the expert system, and is better placed to drive the move toward a more sustainable agri-food system as it involves regionally oriented system innovation, and hence generates development that balances social and environmental factors. We then describe the methods, rationale, and selected locations used in our case study research. Next we explain how two farmers have converted their conventional dairy farms into organic farms by developing short supply chains. In the final section we analyze the adaptation processes and the shift in farm boundaries that have occurred on both farms in terms of novelty production, and we make some remarks on the more general constraints facing the further enhancement of sustainable food production.

\section{Unfolding farm practices}

Farmers can be seen as brokers between nature and society (Toledo, 1990). They work at the interface where society and the natural ecosystem meet in an artificial ecosystem, an agro-ecosystem (Altieri, 1987, 1995, 1999; Sevilla Guzmán \& Martínez Alier, 2006). Through the specific interactions and mutual transformation of humans and living nature (Toledo, 1990), farmers continuously (re)produce and reshape, diminish or improve the natural resource base (Gerritsen, 2002; Swagemakers, 2008; van der Ploeg, 1997, 2008). Agro-ecosystems have been described as dynamic socio-ecological systems (Rammel, Stagl, \& Wilfing, 2007) that are

\footnotetext{
1 "A novelty might emerge and function as a new insight into an existing practice or might consist of a new practice. Mostly a novelty is a new way of doing and thinking - a new mode that carries the potential to do better, to be superior to existing routines" (van der Ploeg et al., 2004, p. 1). Novelties are meant to reach a new, desired farming situation and are part of the process of system innovation employed by farmers (Wiskerke \& van der Ploeg, 2004; Milone, 2009).
} 
subject to a process of continuous adaptation (Holling, 2001; Stagl, 2007; van der Ploeg, 2008). They can be improved by the "agency of actors" (Giddens, 1984) or when "practitioners" pay more attention to optimizing their performance (Warde, 2005). In this sense, these systems represent objectified and accumulated labor (Bourdieu, 1986) and context-related knowledge about the interrelations between the natural and socio-economic resource bases (van Kessel, 1990). Agro-ecosystems are often further strengthened by incorporating new producer-consumer relationships (Sevilla Guzmán \& Martínez Alier, 2006; Holloway, Kneafsey, Venn, Cox, Dowler, \& Tuomainen, 2007), a process that Marsden and Smith (2004) defined as "ecological entrepreneurship."

In farming, the mobilization and conversion of resources and the marketing or re-use of end products are interrelated and mutually adapted processes (van der Ploeg, 2008). This means that "resources can be mobilized from the respective markets (and, thus, enter the process of production as commodities) or they might be produced or reproduced within the farm itself (or within the wider rural community). This implies that 'outputs' can also be oriented in two ways: towards output markets or towards reuse (perhaps after socially regulated exchange) within the farm" (van der Ploeg, 2008, p. 153). The farm can be understood as a series of nested systems, each the focus and locus of co-evolving systems (Farell, 2007). In developing their farm, farmers need to look at and balance the technical, economic domain and socialorganizational domains (Leeuwis, 2004). These domains, or subsystems, are constantly undergoing a process of adaptation, both internally and in their interactions, which result in novelties - small adjustments in one of the many tasks and activities on the farm (Swagemakers, 2002; van der Ploeg et al., 2004; van der Ploeg, Verschuren, Verhoeven, \& Pepels, 2006).

The production and testing of novelties emerges from the tacit knowledge of experienced practitioners. In working toward sustainable food production, farmers' intuitive insights drive them to pursue often complex patterns of action. These insights are based on their experiences of farm development and of the wide range of factors that affect the outcome of context-specific and complicated processes of adaptation. These insights are reflected in and tested, verified and communicated through novelty production (Baars, 2010). Farmers as practitioners employ a "prospective structure" that "has the power of forceful fiction, and opens up space for action" (van Lente, 1993, p. 236). The novelties they create are based on their expectations and generate a wider program of interrelated and mutually reinforcing novelties that might succeed or fail (van der Ploeg et al., 2004, 2006). A set of novelties can be interpreted as a development path (Geels \& Schot, 2007) and the resultant agro-ecosystem reflects the "materialized connections" between nature and society (Gerritsen, 2002; Roep, 2000). Through a process of continuous adaptation, the connection between farming, nature and society is reconstructed in a step-by step fashion.

System configurations that stem from, and are based on, farmers' intuitive insights often remain undervalued and receive little attention (van der Ploeg, 2003, 2008). The ordering "rules" that result from these practices (Giddens, 1984), especially the normative and cognitive rules, differ from the rules of externally designed system innovation (Rip \& Kemp, 1998; van den Ende, 1999). Since the latter stabilize the existing, recognized, and accepted trajectories (Geels \& Schot, 2007), these farmerdeveloped practices often remain "invisible" or at least unnoticed. They can be considered as "niches" or "incubation rooms" where ideas and new patterns or configurations ripen, allowing the potential emergence of radical system innovations (Geels \& Schot, 2007; Hoogma, 2000; Kemp, Schot \& Hoogma, 1998; Wiskerke \& van der Ploeg, 2004). As niches, these practices allow niche actors as well as "outsiders" (researchers, politicians, farmers, people involved in food industries) to learn about the constraints and the requirements of the system innovations being developed (Hoogma, Kemp, Schot, \& Truffer, 2002). 
Novelties are new and promising artifacts, concepts, approaches, organizations, and arrangements that are at a stage of infancy. They are immature and vulnerable and still have to prove their validity and value, especially outside the contexts in which they have been developed. On the basis of our case study research, we argue the need for a different organization of social, ecological, and economic relations at higher levels of aggregation (Altieri, 1989), that is, at the territorial level. Our analysis of the practices of farmers who work toward increasing their sovereignty of production leads us to call upon scientists, politicians, farmers, and those involved in food industries to recognize and include the potentials of agroecology and the "rules" implicit in reconnecting farming, nature, and society.

\section{Applied research methods}

We document two cases of farmers who are reconnecting nature and society by unfolding their farming practices in ways that improve the socioecological performance of their farms. We have used a case study research method (Yin, 1984), which provides contextdependent knowledge (Campbell, 1975; Flyvbjerg, 2006) that generates detailed insights about what is happening in the situations studied (Stake, 2000). We have adopted an ethnographic approach (Spradley, 1979), carrying out direct observations, analyzing written documents (articles in newspapers, farming magazines, and on websites) and held interviews that consisted of "active and methodical listening" (Bourdieu, 1996). In order to gain "extensive" knowledge of the subject (Bourdieu, 1996), we spent some time living in the case study areas (see figure 1) and joining in with the farmers' daily activities. Sometimes we stayed for a day, other times for weeks or even months. We drove the tractor, helped with seeding, harvested the hay, milked cows, made cheese, went to farmers' markets, drove the van for home deliveries, got to know the farmers' consumers, and became consumers ourselves. This fieldwork experience (Fetterman, 1989) taught us much about the daily life of the practitioners. Through the application and combination of different sources of information and different research methods (Mathison, 1988; Verschuren \& Doodewaard, 1999) we increased the internal validity of the field research.
Figure 1. Map Indicating Locations of Case Study Farms in the Netherlands and Spain

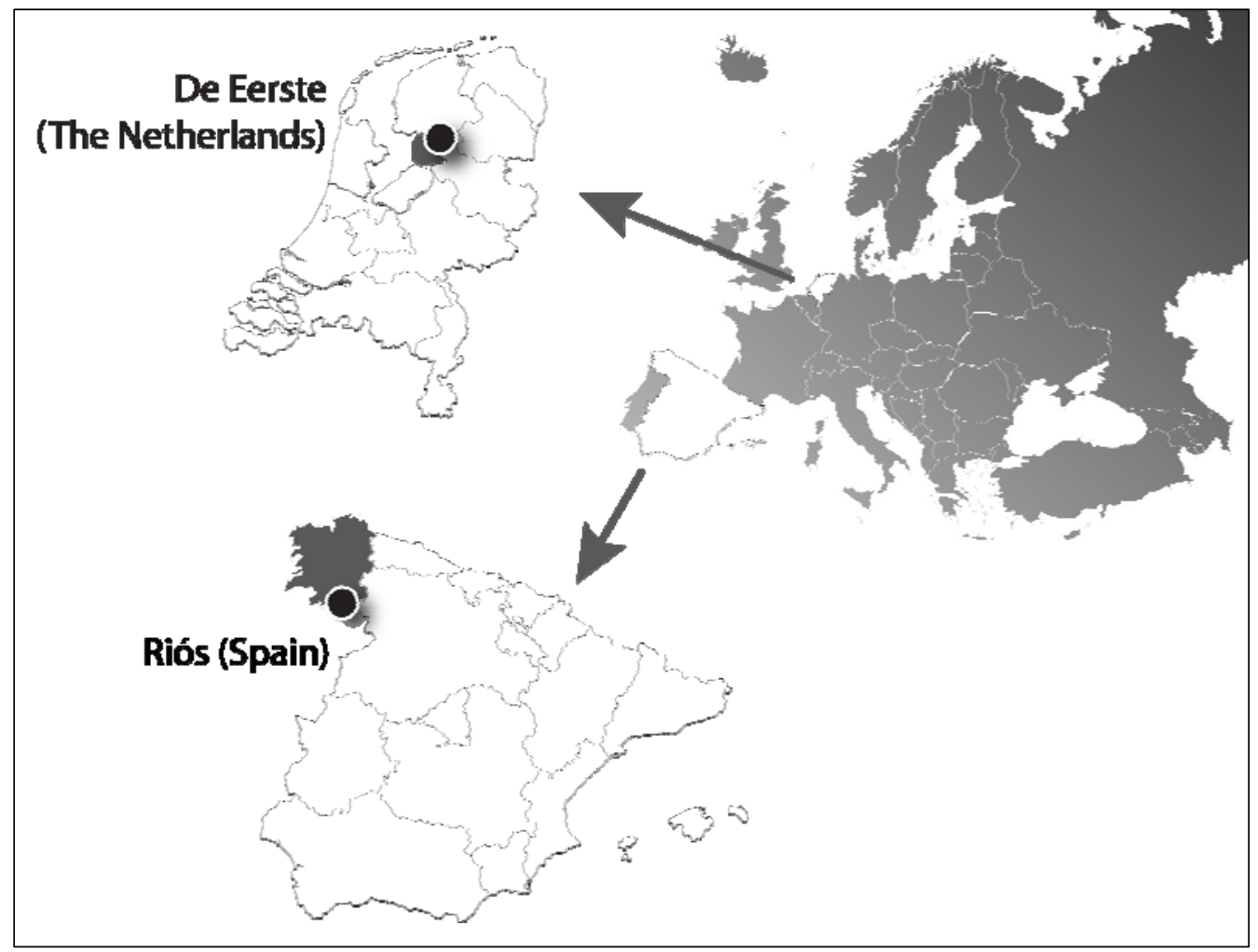


As part of the research process, we planned questions and developed interview protocols to ensure that the interviews covered all topics of interest and drew on an ethnographic tradition to understand the farmers' life histories. Alongside formal interviews, we had frequent informal discussions with our subjects about topics of mutual interest. In the interviews, some lasting two hours, others much shorter, but always in situ (Svendsen, 2006), we co-constructed with the interviewee the meaning of their practices (Heyl, 2001) and benefitted from the rich details they provided.

\section{Results}

In this section we describe how the two farmers converted their conventional dairy farms into organic production systems and established new producer-consumer relationships. In the first two sections we discuss the specific novelties on the two farms. In the third section we discuss the interrelations of the novelties as part of a newly evolving (unfolding) system configuration at each farm.

Organic farming in a polder in the Netherlands In 1987, Gerrit and Bertiene Marsman took over "de Eerste" (literally "the first"), originally an experimental state farm that was the first to be established on the virgin sandy soils after the Noordoostpolder (Northeast Polder ${ }^{2}$ ) was created in 1942. The farm was atypical of the rest of the polder in that it was on sandy (as opposed to clay) soils and had been intensively fertilized to make it productive. The couple began by converting this farm into an organic dairy farm. The first year they started cheese production, partly as a way of increasing their income, but more because there was a very limited market for fresh organic milk at that time, so cheese-making allowed for more flexible sales. During an interview about the

\footnotetext{
${ }^{2}$ According to Wikipedia, "A polder is a low-lying tract of land enclosed by embankments (barriers) known as dikes, that forms an artificial hydrological entity, meaning it has no connection with outside water other than through manuallyoperated devices" (Wikipedia, "Polder," 2011).
}

conversion to organic farming, Gerrit explained his personal motivation:

I use the farm to shape a type of ambition. I live with a certain idea. You have to work out things together. You are responsible for each other and for other parts in the world. This farm and these soils, partly determines what happens in other parts of the world. G. Marsman

Gerrit sees organic farming as reducing the environmental impact of farming and providing better conditions for the animals and people who work on the farm as well as in other parts of the world, since organic farming has reduced impact on farmers and the natural resource base overseas (in the Global South). Besides providing environmentally sound and healthy food, Gerrit and Bertiene supply organic food products to households with a wide range of incomes. Over time a series of novelties (outlined below) has evolved that have gradually become more strongly interrelated. This strategy (i.e., a mixed farm) has enabled them to develop their dairy farm much less intensively than most of their colleagues. Typically a dairy farm would have 150 milking cows; Gerrit and Bertiene can generate equivalent revenue from just 60 .

\section{On-farm milk processing}

Converting milk into cheese, yogurt, butter, and buttermilk is labor-intensive, but adds value to milk production. The farm annually produces 33 tons of cheese, one-third of which is sold through short supply chains. On-farm milk processing keeps transport costs low and results in fairer prices for both producer and consumers.

\section{New breeding objectives}

A smaller breed of cow produces fewer units of milk, but per unit it is richer in protein and fat. This means that similar quantities of cheese can be produced with less input of feed. Although the breed is not optimized for beef production, the less productive cows are slaughtered and their meat sold as mince in a short supply chain. 
A Holstein-Friesian produces around 9,000

liters [2,378 gallons] of milk with $3.4 \%$

protein and $4.2 \%$ fat, thus around 570

kilogram $[1,257$ pounds $]$ of fat and protein.

To produce this quantity of milk, they require 2,430 kilogram $[5,357$ pounds $]$ of

concentrates, about $27 \%$ of the total production. On the other hand, the Jersey gives 6,000 liters [1,585 gallons] with 4\% protein and $5.5 \%$ fat - the same volume of protein and fat - but only consumes 1,200 kilogram [2,646 pounds] of concentrates, representing $20 \%$ of the production. For me, cross-breeding Holstein and Jersey is very attractive. - G. Marsman

\section{Short supply channels}

The dairy products, meat, eggs, and vegetables produced at the farm are sold through several venues: in the farm shop, at farmers' markets, and via a home-delivery system. Selling a range of organic and fair-trade products generates extra cash flow that makes the shop profitable.

\section{Small-scale activities}

Raising pigs and poultry often involves high veterinary, feeding, and labor costs. For Gerrit, however, keeping pigs and poultry helps maintain the balance of the farm. Whey, a residue of the cheese-making process, is used to feed five pigs, and the manure of the 500 chickens is used to fertilize the vegetable fields. The labor input for these activities is supplied by the farmers, and the meat and eggs are sold in the farm shop. Overall these activities contribute to the economic and ecological performance of the farm.

\section{Manure management}

A deep litter house provides shelter for the dairy cows. Fresh straw is put in the house daily in order to keep their udders clean, an important consideration since "dirty" milk results in bad cheese quality. The resultant manure is low in emissions and there are few losses to the groundwater system. Some slurry is also produced, which is used as liquid manure for the horticultural crops (see novelty 6, below). This also reduces susceptibility to disease.

\section{Growing cash crops}

Soon after taking over the farm, the idea of growing vegetables emerged. This required investments in tractors, a forklift truck, and storage capacity, but these have benefited the farm as a whole. For example, the forklift that is used to transport boxes of vegetables is also used to sweep the fodder in the feed alley. Plant residues are recycled to improve the fertility and structure of the soil. The turnover of the farm has increased, although running it requires more labor input and this requires some organization. This system can best be described as grassland rotation: giving over one-quarter of his grassland to crop production each year. This enables the land to be used more intensively for crop reduction, while minimizing the risk of erosion that is inherent to arable production on these sandy soils.

\section{Cooperation between neighboring farmers}

Diversifying and expanding activities requires extra labor and machinery. Growing potatoes or making straw or silage requires special machinery and involves peak labor periods. A group of neighboring farmers work together, pooling their machinery and labor to carry out these jobs more efficiently. Once the jobs at one farm have been done, the group moves on to the next.

\section{Mobilizing labor}

Growing vegetables expanded the labor demands on the farm, and it was decided to acquire a horticultural manager who would act as a partner and have a stake in the farm. This creates a new way of using human resources. This approach is extended wherever possible to other employees, creating relationships that more akin to partnerships than employer-employee relations.

People are responsible for what they do. My philosophy is that one should see what motivates people, what interests them, what they like to do, and what they will make out 
of something. Then, stimulate this. G. Marsman

The farm land, buildings and machinery are owned by the farmers, and the partner contributes his labor time. A structure has been created to motivate both parties. Both are dependent on the economic results of the activity, and they also share the risks and benefits. The farmers provide the land, manure, machinery, and 500 hours of Gerrit's labor per year; their partner, the manager, invests 2,500 hours in planting, harvesting, and selling the products. All these costs are later recalculated in labor hours. A successful harvest will give a bonus of about $15 \%$ in the salary of the partner. This provides a motivation for him to produce as efficiently and accurately as possible, and also gives incentives to use the machinery and land provided by the farmers efficiently. The partner has gradually invested in capital-intensive production factors, thereby acquiring more "hours" (all input factors are calculated in terms of hours), which in turn increases his share of the income when the harvest is sold. The production factors can also be lent or hired to others, again generating revenue for the partner. When there is a high demand for labor (say for sowing or harvesting), the partner can make use of labor available in other parts of the farm. When labor (his or that of his workers) is not in demand, it can be provided for other activities on the farm.

\section{Shared use of mechanization}

Machinery is in use in several parts of the farm. For example, there is a powerful tractor used to plough, mow, and harvest straw. There are also several old tractors that are used for smaller jobs, such as seeding, weeding, and bringing the straw from the field to the cattle sheds.

I look critically at how the machinery will be used. I calculate by the hour and the hectare to see what is worth investing in. By cooperating, you can reduce the costs of mechanization. With 600-700 hours of tractor work per year, it makes sense to buy a second-hand tractor. With 1,000 hours per year, a new one becomes profitable. In horticulture, the tractors work 300-400 hours, and new tractors are certainly not profitable. But a hard job like weeding needs a mechanical solution, which can be provided by a smaller, second-hand tractor.

- G. Marsman

For time-consuming and heavy activities, a powerful tractor pays for itself. While spending similar amounts on diesel, the job is done more quickly. Lacking the money to buy a heavy-duty tractor, Gerrit hired one from a neighbor for a while. Once enough money was available (and his colleague became busier), buying the new, powerful tractor was attractive.

\section{Fodder production in nature reserves}

The farmers also rent a three-hectare [seven-acre] nature reserve that is used for hay production. This is used to feed the yearlings, which are kept to increase the herd. While it takes as much time as making silage on the farm, this allows them to grow cash crops and to pasture dairy cattle on the farm itself. In dry weather it is cheaper to make hay than silage. An even cheaper option would be to allow the yearlings to graze on the nature reserve, but this is not allowed under the terms of the lease.

\section{Optimizing landscape and natural values} Farmland on polders is normally very intensively managed, but Gerrit manages to find space on the farm to include features that enhance the ecological robustness of the farm. There is a subsidized pond, which attracts birds and helps drain the land during wet periods, leaving it drier and more easily worked. Bushes and trees have been planted along the farm tracks. These provide habitats for small animals, provide shelter against rain and heat for the cows, and help prevent the sandy soils from being blown away.

\section{Increasing organic matter content}

Improving the organic content in the soil is a priority. As an experiment, over the last five years 10,000 tons of compost (equivalent to 300 fully loaded trucks) bought in off the farm have been 
spread over 50 hectares (124 acres) of land. Whereas nutrient flows (e.g., dairy products and vegetables) are usually only directed to the market, on this farm they are also circular. The compost is applied either after the grassland has been plowed (80 metric tons per hectare, or 36 U.S. tons per acre) or before the vegetables are harvested (40 metric tons per hectare, or 18 U.S. tons per acre). This experiment was based on having access to a free resource (the compost), but the cost of transporting and spreading the compost was very real and has been calculated at $€ 30,000$ (approximately USD39,000) over the five-year period. The results, in terms of improved organic content, are still to be checked, but it is expected that it will have increased substantially.

\section{Organic Farming in a Mountainous Area in Galicia, Spain}

Galicia has experienced decades of massive emigration from its poor rural areas, resulting in high concentrations of older residents in these areas. The land and farm structure as a consequence of the emigration also provide few possibilities for earning a living; small-scale and widely dispersed field parcels complicate the viability of pasturing cattle. In 1984 José Luis Páz established a small dairy farm in Riós, a village in the mountainous area close to the border between Portugal and Spain. Although his family was from the village, he started as a young "newcomer" from the city. Following advice from the extension service, he started small, with six milking cows. $\mathrm{He}$ planned to improve the farm, and by tapping into subsidies he invested in buildings, machinery, and in purchasing additional milk quotas to expand the farm over the years. However, José Luis began to have doubts about this intensive way of farming. Starting in the early 1990s, he started to be concerned about the health problems of his herd. The cows regularly became infected by disease, shortening their life span and requiring a high input of antibiotics and anti-inflammatories. In 1998, he was invited to visit organic farms elsewhere in Europe at a time when he was thinking about changing things at his farm. This gave him the opportunity to learn about alternatives, and after he returned from the trip he converted his dairy farm into an organic beef cattle farm. He sold his milk quota, began breeding a local cattle breed, and started a cooperative. In the talks we had with José Luis, he explained to us that he lacked a background in farming:

I came here with a theoretical ambition. I had an idyllic idea about the countryside that was rooted in my youth. My parents migrated to the city when I was seven years old. But I still remembered how I went to the fields with my father, and we took care of the cows and the land. It seemed like a good life and the idea of that beauty remained inside me. - J. L. Páz.

José Luis learned that his idea of the rural life differed from that of the people who had remained in the village. He searched and experimented with solutions to his farm's problems, a great many of which failed, yet he has accomplished his wish to live a good life and to be working in, and taking care of, the land. While not always successful, his experiments have resulted in the production of a series of novelties as described below, which gradually became more strongly interrelated.

\section{Creating a cooperative}

The cooperative supplies a range of inputs (organic fodder, solar panels, fencing materials), advice on organic production methods (particularly on preventive, curative, and antiparasitical medication), and administrative support to meet the requirements of agro-environmental and organic production schemes. It also provides transport to the slaughterhouse and sells the organic beef.

\section{Short supply channels}

Meat is sold directly to clients as vacuum-packed fresh meat. Customers include individuals, organic shops, supermarkets, and consumer associations. There is also a growing customer base among professional butchers and restaurant owners who appreciate the natural identity and taste of the meat. Customers can also buy half a cow, paying a 
price that is based on the slaughter weight of the animal.

\section{Improving animal health}

Alternative ingredients, such as bicarbonate of soda and yucca extract, are used to protect the cattle's digestive system, instead of conventional medicines. This results in healthier cows with a longer life span, lower veterinary costs, and "safer" meat. Such an approach requires farmers to have an open attitude to experimenting with new, often not yet scientifically "proven profitable" fodder strategies.

\section{Changing from dairy to beef production}

The change from dairy to beef production involved less labor input and resulted in lower costs for external inputs. This was helped by using breeds that are well adapted to local conditions. The reduced cash flow is compensated for by selling the meat in short supply chains.

\section{Breeding autochthonous beef cattle} José Luis wanted to introduce Vianesa blood into the herd. This is an autochthonous breed which is perfectly adapted to the mix of productive valley grasslands and less productive mountain pastures. He initially acquired and bred a 20 -year-old Vianesa cow that he located in a remote rural village. After it died, crossbreeding was continued by buying a bull, purchasing sperm, and bringing in cattle from elsewhere. In addition to introducing Vianesa bloodlines, José Luis has also introduced the Cachena breed to his herd. This is a small indigenous breed that is well adapted to the poorest pastures, especially to monte bajo (mountain scrubland). As smaller breeds of cattle, these animals have a lower slaughter weight than conventional breeds like the Galician rubia and Limousin. Subsidies have helped get more farmers involved in crossbreeding these endangered autochthonous breeds: a subsidy of $€ 200$ (approximately USD260) per calf compensates for the 40-50 kilograms (88-110 pounds) difference in weight.

\section{Accessing land}

Rather than entering the formal land market, José Luis has achieved access to land through informal arrangements with family members. Some 100 hectares (247 acres) of land, all small and scattered plots, is "leased" annually in this way, generally in return for meat products.

\section{Pasturing the cows}

Cattle grazing outside find heather and other medicinal plants.

My cows not only eat grass, they also eat the lower branches of the trees and the bushes and scrub. Some of these bushes help keep them clean from parasites. - J. L. Páz

Only in summer, in the driest period when the grass production stagnates, and in winter, during the coldest days, do the cattle remain stabled at the farm, where they are fed with silage and hay. The silage and hay provide sufficient energy for the beef cattle. Only when fattening the calves in the last two months before slaughter are any concentrated inputs required.

\section{Differentiating meat quality}

Consumers recognize and appreciate the flavor, color, and texture of autochthonous breeds. Apart from Vianesa, which makes up $90 \%$ of the herd, the Cachena breed is highly appreciated by professional butchers and restaurant owners, who pay a premium price for this meat.

\section{Improving organic matter content}

The fertility of the soil is improved by leaving the grassland unturned. The plow has been sold and the land is only turned with a rotavator if needed. This saves costs and results in a richer top layer of soil life. The grass mix is richer and more diverse.

\section{Composting manure}

Soil fertility is further improved by adding a catalyst to the manure. The catalyst, developed in Germany, stimulates worms to grow faster so they more rapidly transform the manure into humus. Although making compost requires more labor, this pays dividends in terms of improving the soil fertility and stimulating grassland production. 
Table 1. Overview of the Novelties Developed at the Farms

\begin{tabular}{ll}
\hline \multicolumn{1}{c}{ Novelties at the Dutch farm } & \multicolumn{1}{c}{ Novelties at the Galician farm } \\
\hline 1. On-farm milk processing & 1. Creating a cooperative \\
\hline 2. New breeding objectives & 2. Short supply channels \\
\hline 3. Short supply channels & 3. Improving animal health \\
\hline 4. Small-scale activities & 4. Changing from dairy to beef production \\
\hline 5. Manure management & 5. Breeding autochthonous beef cattle \\
\hline 6. Growing cash crops & 6. Accessing land \\
\hline 7. Cooperation among farmers & 7. Pasturing the cows \\
\hline 8. Mobilizing labor & 8. Differentiated meat quality \\
\hline 9. Shared use of mechanization & 9. Improving organic matter content \\
\hline 10. Fodder production in nature reserves & 10. Composting manure \\
\hline 11. Optimizing landscape and nature values & \\
\hline 12. Increasing organic matter content & \\
\hline
\end{tabular}

Figure 2. Transformation of Input-Output Relations: The Novelties Created at Both Farms

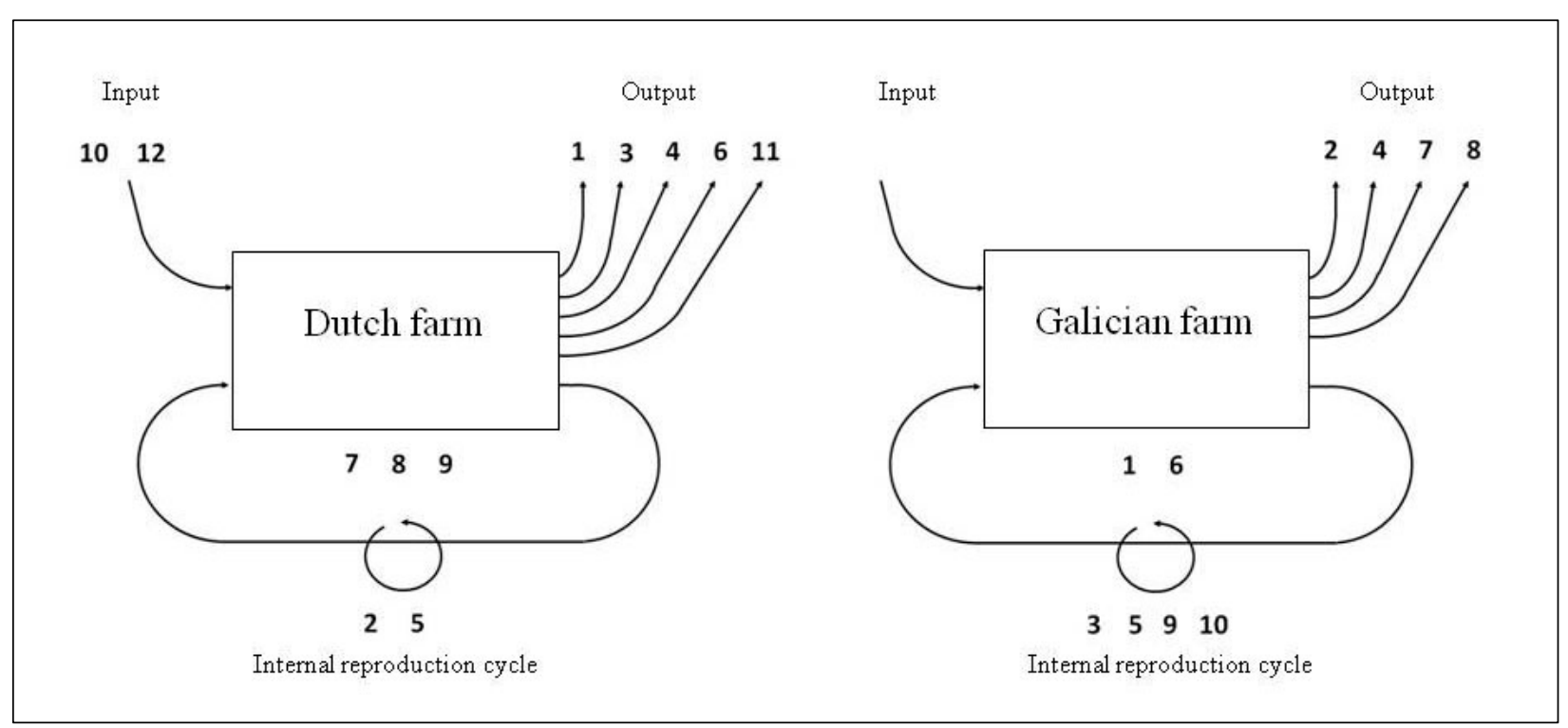

Source: Adapted from van der Ploeg (2008, p. 153).

New On-Farm Activities and a Shift in

\section{Farm Boundaries}

Table 1 provides a summary of these novelties, showing the order in which the novelties were developed by the farmers. Over time, the novelties came to mutually support each other and unfold into improved and more efficient input-output conversion rates (van der Ploeg, 2008). Figure 2 illustrates how this works. The conversion to organic farming and the diversification of farm activities resulted in a shift of farm boundaries, leading to a range of adjustments and new activities being established at both farms.

In the left side of figure 2, we see how at the Dutch farm the milk produced is processed into cheese (novelty 1). This affects the breeding strategy at the farm, leading the farmer to search 
for a cow producing more protein and fat per unit of milk (novelty 2). The cheese is sold through short supply channels (novelty 3 ): a small farm shop, a home delivery service, and several farmers' markets. Apart from dairy products, more than 600 dry products are sold, together with meat and eggs produced on the farm (novelty 4 ). These new activities support other ones: the manure from the chickens is used in horticultural activities, and the whey from the cheese production and vegetable leftovers from the shop are fed to the pigs (novelty 5). Horticulture and arable crops (novelty 6) generate a demand for labor and a higher turnover per hectare, but could potentially reduce soil fertility. To compensate for this, soil fertility is sustained by the input of manure produced on the farm (novelty 5) and the application of compost

from municipal recycling programs (novelty 12). The conversion to organic farming resulted in a range of new activities, which required a reorganization of farm management. Local farmers exchange their labor and machinery (novelty 7 ) and partners are drawn in to work in different partnerships created at the farm (novelty 8). The machinery and labor available in the partnerships is shared (novelty 9), increasing efficiency in the use of both in all areas of the farm. Furthermore, land use is optimized by creating new elements in the landscape (novelty 11): the construction of a pond has improved water management; trees act as windbreaks and reduce soil erosion. The grassland lost to horticulture, arable farming, and landscape elements are at least partly compensated for by grassland production in a nearby natural reserve (novelty 10).

Figure 2 also shows the effects of conversion to beef cattle production at the Galician farm (in the right side of the figure), which involved selling organic meat through a cooperative. These two changes led to a range of other adjustments being made at the farm. A cooperative (novelty 1 ) supplies a wide range of services to the farmer and his neighbors. Initially, it was difficult to convince other farmers to become involved, but nowadays about 70 farmers are members, which strengthens the cooperative's position, especially in negotiations and mediation. The cooperative provides transport facilities (a truck), organic fodder, management (organic certification requirements), technical support, and the information needed to participate in subsidized programs. The organic beef products are sold through various distribution channels all over Spain (novelty 2), and animal health is improved by a reduction in their consumption of concentrates and the routine use of preventive medicines (novelty 3). At the farm, dairy production has been converted into beef cattle production (novelty 4). Autochthonous breeds (novelty 5) such as the Vianesa, Cachena and Caldelás are used. These are better suited to the poor grazing conditions in the area. The Caldelás is particularly well fitted to monte bajo, and their grazing restores this land to productive pasture. These varieties also help control invasive bushes and scrub, which is ignored by more productive cattle, which also improves the quality of the pasture over time. Autochthonous breeds recover the traditional functions of the monte bajo, which includes providing animal feed, cereals, fruits, and organic manure (see also Soto, 2006; Domínguez García, 2007). Abandoned or neglected land is accessed through family relationships (novelty 6). Bringing the land back into use diminishes the risk of forest fires in the mountainous areas and revitalizes a resource that was once a crucial element in sustaining small-scale agriculture. However, this land arrangement may not be a longterm solution, as the lack of a legal contractual status could endanger the continuity of the farm. This might require new solutions in the future. By grazing in natural fields with mixed vegetation, the cows benefit from ingesting medicinal plants (novelty 7), improving the quality and flavor of the meat (novelty 8 ) and reducing their susceptibility to disease and the need for antibiotics. No longer renewing the grassland improves the organic matter content of the soil and increases the varieties in the grassland (novelty 9). Initially, the level of grassland production fell as the soil regenerated, but it has since recovered and can now provide sufficient grass and fodder to feed all the beef cattle at the farm while also improving the taste 
and quality of the meat. Besides saving costs and benefitting the natural environment, the method saves labor time - time that the farmer invests in marketing the beef products and adding extra value per unit of product. The recent reduction in subsidies for maintaining indigenous breeds and cross-breeding is being at least partially compensated for by selling the meat to specialized butchers and restaurant owners. These cows improve the monte bajo, bringing it back into productive use and thereby creating another asset for the farmers, and reducing the risk of fires. The monte bajo can be plowed and fertilized with 'Xesta' (Citysus scoparius), a native leguminous plant variety that grows well in there. Xesta also contributes to improving the quality of the manure (novelty 10).

\section{Analysis and Discussion}

On both farms, the novelties have been developed across a "broad spectrum of the domains of farming" (Leeuwis, 2004, p. 64): the technical domain (soil fertility, crop protection, animal health, production and yield, storage facilities, spatial organization of the farm, regeneration of production potential, etc.); the economic domain (income, profitability, marketability, taxes, investments, cash flow, credit, fixed costs, variable costs, etc.); and the domain of social-organizational relationships (relationships with input-providing organizations, organizations on the output side, state organizations, certification institutes, members of the household, other farmers, community members, farm laborers, etc.). These changes began with more technical tasks in the technical domain. This was followed by adapting tasks in the economic domain and the domain of social-organizational relationships. These in turn resulted in further adaptations in all different domains, generating an unfolding of farm practices.

For example, in the technical domain, the improvement of soil fertility is crucial. In the Dutch case, soil fertility has been improved by the application of compost (novelty 12) and the use of grasslands in a nearby nature reserve (novelty 10). These novelties have led to an increase in the input of organic matter into the farm system. In the Spanish case, soil fertility has been optimized by changing from dairy production to beef production (novelty 4) and through the use of autochthonous breeds (novelty 5). These novelties decrease the pressure on soil fertility. The use of the monte bajo, an asset that is currently less than fully employed, would further increase the soil fertility of the productive grasslands. In both cases, the animals have been selected in response to changes in the farmers' production objectives. At the Dutch farm, where milk is processed into cheese (novelty 1), smaller breeds more efficiently turn feed and fodder into proteins and fat (novelty 2), which allows the production of a similar amount of cheese using less milk and less feed and fodder intake. At the Spanish farm, a similar shift in production has occurred: smaller animals are used (novelty 5) that supply meat that is rich in taste (novelty 8 ) and finds its way to consumers through short supply chains (novelty 2). The Dutch case also uses short supply chains to sell the food produced on the farm (novelty 3). Although the contexts of the farms differ, as does the physical distance to markets, both farms are selling quality products with a local character and identity via short supply chains. Attracting, informing, and engaging consumers in short supply chains allows for a further diversification of production activities. The Dutch farm produces pigs, eggs (novelty 4), and cash crops (novelty 6). The Spanish farm combines the use of autochthonous breeds (novelty 5), methods of accessing land (novelty 6), improving the natural resource base (novelty 7 ), and improved meat quality (novelty 8).

Producer-consumer relations play a key role in sustaining the improvements these farmers have made to their socio-ecological systems (van der Ploeg, 2010). The extra value added through short supply chain channels "pays the farmer back" for a more labor-intensive method of food production, for the knowledge that needs to be accumulated, and the use, reproduction, and possible improvement of the natural resource base. These case studies show how the farmers convert "ecological" capital into economic capital. This is a mutually reinforcing process: the short food supply chains 
sustain the socio-ecological performance of the farms and vice versa. The coordination of the tasks and the opportunities within the domain of socialorganizational relationships allow both farmers to expand their farm activities. The diversification of activities at the Dutch farm and the access to more land at the Spanish farm both result from the farmers' capacity to mobilize and optimize locally available resources. In the Spanish case, access to land (novelty 6) is a privilege not granted to everyone, which is paid back in kind. In the Dutch case, similar mechanisms of reciprocity can be recognized: in return for access to the land, the partner returns a "share" of the production to the owner. Hence, the partner has opportunities to expand his activities (novelty 8), which provides new resources (novelty 9) to all those involved.

These dynamics show how differentiating production activities and organizing short supply channels influence patterns of production and reproduction, and create new relationships in the social-organizational domain. In both cases, external inputs are being replaced by internally produced or reproduced resources: soil fertility, local or adapted breeds, food products, labor, and locally specific knowledge about the production process. Both farmers "farm economically" (Dominguez Garcia, 2007; van der Ploeg, 2000), and this improves the overall performance of the socio-ecological systems.

In contrast to conventional food production, the farm activities are developed in a way that increases the autonomy of the farmer. In this sense, these farming practices represent "robust" models of food production (Wiskerke, 2007). The case study research shows how practitioners can create their own responses to the degradation of natural resources and the agrarian crises, particularly the frequent outbreaks of livestock diseases associated with intensive farming, which appear to be a result of the increasing disconnection between farming, nature, and society (van der Ploeg, 2006).

As we have argued above, these system configurations provide a "prospective structure" (Hoogma et al., 2002; van Lente, 1993) for alternative pathways along which farming, nature, and society can be reconnected. These systemic configurations unfold in different contexts, but they share the common characteristic that the adaptations are guided by a re-orientation toward the local ecological and socio-economic resource base.

The unfolding of farming within a local context can be further strengthened when scientists explore, test, and verify the interrelations between novelties, while politicians and policy-makers pursue an objectives-led policy — instead of implementing prescriptive measures - that allows for and stimulates the exchange of novelties between producers and promotes scientific research on promising novelties. While it may be difficult to find more than a few farmers who manage to combine a successful social-ecological and economic performance, as exemplars of good practice they should be more involved in strategies to promote and disseminate the much-needed transition to sustainability. They provide a living example of how it can be achieved.

The niche innovations that are developed and carried out by small networks of dedicated niche actors can only be more widely diffused if they are linked up with processes in the "outside" world (Geels \& Schot, 2007; Klerkx, Aarts, \& Leeuwis, 2010; Schot \& Geels, 2008). This uptake implies a shift in the dominant socio-technical regime, i.e., the grammar or rule set in the complex whole through which activities of actors (both insiders and outsiders) are structured (Rip \& Kemp, 1998), with the regime here being the mainstream agroindustrial expert system. Such shifts generally occur when the current regime realizes that the existing technological opportunities are exhausted, when governmental policies dramatically change, and/or when new sets of social values emerge (Kemp, Schot, \& Hoogma, 1998). Regime shifts are complex transitions (Geels \& Kemp, 2000) that entail a gradual but continuous process of adaption alongside structural changes in the character of society (Rotmans, Kemp, van Asselt, Geels, Verbong, \& Molendijk, 2000). Each adaptation 
and/or link within the new system configuration - the farms in these case studies - involves negotiations, renegotiations, and, usually, the construction of new institutional relations at the regime level (van der Ploeg, van Broekhuizen, Brunori, Sonnino, Knickel, Tisenkopfs, \& Oostindie, 2009). It is important that the actors involved in ensuring the stability of the current regime (Geels \& Schot, 2007) are aware of the potential of alternative system configurations.

Hence, citizens, farmers, researchers, and politicians should be informed and incorporated in the "real stories" of innovating famers who develop "radical" novelties in niches (Schot \& Geels, 2008). We are convinced that the descriptive presentation of the process of novelty production in the case studies, as well as the analysis of the adaptation process itself, have roles to play in helping to build understanding of how we can start building a more sustainable agri-food system.

\section{Conclusions}

Our comparative ethnographic case-study research shows how practitioners establish new system configurations that reconnect farming with nature and society. The move toward a sustainable agrifood system requires novelty production: a farmerdriven adaptation process that is specific in place and time, results in improved social and environmental relations, and allows for economic progress. At the farms in the case studies a series of adjustments was identified, which we have conceptualized as novelties. It is through novelty production that the activities at the farms and, hence, the characteristics (or configuration) of farming change. In the Dutch case, the farmer has converted a conventional dairy farm into a multifunctional organic farm with on-farm cheese processing and vegetable production. In the Spanish case, the farmer converted a conventional dairy farm into an organic beef cattle farm by using and reproducing autochthonous breeds. At both farms, the process of unfolding farm practices resulted in a shift of farm boundaries: both configurations are sustained by the construction of short food supply chains.
Such reconfigurations are in stark contrast to the model advocated by the modern agriculture industry. Many of the structures of this regime in terms of food processing, distribution, and retail as well as its regulatory aspects stifle regionally specific, small-scale, diversified configurations. Since established socio-technological regimes are generally resistant to change (Geels \& Schot, 2007), the further unfolding of these new configurations is likely to be constrained by either strategic obstruction or inadequate support from the dominant socio-technical regime. Although the establishment of successful transitions cannot be guaranteed by "ideal type" pathways (Geels \& Schot, 2007), we think it is important to draw attention to the creativity and success of these farmers who are building a future in what are often seen as the margins of society.

\section{Acknowledgements}

We are indebted to the farmers who took an interest in our project, shared their viewpoints and concerns, and spent much time explaining subtle aspects of their adjustments and activities. We thank Jan Douwe van der Ploeg and Dirk Roep of the Rural Sociology Group at Wageningen University (The Netherlands) for their fruitful input during our fieldwork. We are also grateful to Nick Parrott (www.textualhealing.nl) for his valuable editing work and to Armando González for creating the map of the case study locations. Also, we thank the anonymous peer reviewers of our initial manuscript and the JAFSCD editors for their valuable comments and contributions to improve our work. It has been great working with all of you!

\section{References}

Altieri, M. A. (1987). Agroecology: The scientific basis of alternative agriculture. Boulder: Westview Press.

Altieri, M. A. (1989, November). Agroecology: A new research and development paradigm for world agriculture. Agriculture, Ecosystems and Environment, 27, 37-46. http://dx.doi.org/10.1016/01678809(89)90070-4 
Altieri, M. A. (1995). Agroecology: The science of sustainable agriculture (2nd ed.). Boulder, Colorado: Westview Press

Altieri, M. A. (1999). Agroecología: Bases cientificas para una agricultura sustentable. Montevideo: NordanComunidada.

Baars, T. (2010). Experiential science, towards an integration of implicit and reflected practitionerexpert knowledge in the scientific development of organic farming. Journal of Agricultural and Environmental Ethics, 24(6), 601-628. http://dx.doi.org/10.1007/s10806-010-9281-3

Barham, E. (2003). Translating terroir: The global challenge of French AOC labeling. Journal of Rural Studies, 19(1), 127-138. http://dx.doi.org/10.1016/S0743-0167(02)00052-9

Bourdieu, P. (1986). The forms of capital. In J.G. Richardson (Ed.), Handbook of theory and research of sociology of education (241-258). New York: Greenword.

Bourdieu, P. (1996). Understanding. Theory, Culture and Society, 13(2), 17-37. http://dx.doi.org/10.1177/026327696013002002

Campbell, D. T. (1975, July). "Degrees of freedom" and the case study. Comparative Political Studies, 8, 178193.

Domínguez García, M. D. (2007). The way you do, it matters: A case study: Farming economically in Galician dairy agroecosystems in the context of a co-operative (Doctoral dissertation). Wageningen University, Wageningen, the Netherlands.

Farell, K. N. (2007). Living with living systems: The coevolution of values and valuation. International Journal of Sustainable Development \& World Ecology, 14, 14-26. http://dx.doi.org/10.1080/13504500709469704

Fetterman, D. (1989). Ethnography. London, U.K.: Sage. Flyvbjerg, B. (2006). Five misunderstandings about casestudy research. Qualitative Inquiry, 12(2), 219-245. http://dx.doi.org/10.1177/1077800405284363

Geels, F. W., \& Kemp, R. (2000). Transities vanuit sociotechnisch perspectief: Achtergrondrapport voor het vierde nationaal milieubeleidsplan (NMP-4). Maastricht, the Netherlands: Maastricht Economic Research Institute on Innovation Technology (MERIT).
Geels, F. W., \& Schot, J. (2007). Typology of sociotechnical transition pathways. Research Policy, 36, 399-417. http://dx.doi.org/10.1016/j.respol.2007.01.003

Gerritsen, P. R. W. (2002). Diversity at stake: A farmers' perspective on biodiversity and conservation in western Mexico (Doctoral dissertation). Wageningen University, Wageningen, the Netherlands.

Giddens, A. (1984). The constitution of society: Outline of the theory of structuration. Cambridge, U.K.: Polity Press.

Heyl, B. S. (2001). Ethnographic interviewing. In P. Atkinson, A. Coffey, S. Delamont, J. Lofland, \& L. Lofland (Eds.), Handbook of ethnography (pp. 369383). London: Sage.

Holling, C. S. (2001). Understanding the complexity of economic, ecological, and social systems. Ecosystems, 4, 390-405. http://dx.doi.org/10.1007/s10021001-0101-5

Holloway, L., Kneafsey, M., Venn, L., Cox, R., Dowler, E., \& Tuomainen, H. (2007). Possible food economies: A methodological framework for exploring food production-consumption relationships. Sociologia Ruralis, 47(1), 1-19. http://dx.doi.org/10.1111/j.14679523.2007.00427.x

Hoogma, R. (2000). Exploiting technological niches: Strategies for experimental introduction of electric vehicles (Doctoral dissertation). Enschede, the Netherlands: Twente University Press.

Hoogma R., Kemp, R., Schot, J., \& Truffer, B. (2002). Experimenting for sustainable transport: The approach of strategic niche management. London and New York: Spon Press.

Kemp, R., Schot, J., \& Hoogma, R. (1998). Regime shifts through processes of niche formation: The approach of strategic niche management. Technology Analysis and Strategic Management, 10, 175-196. http://dx.doi.org/10.1080/09537329808524310

Klerkx, L., Aarts, N., \& Leeuwis, C. (2010). Adaptive management in agricultural innovation systems: The interactions between innovation networks and their environment. Agricultural Systems, 103, 390400. http://dx.doi.org/10.1016/j.agsy.2010.03.012

Lang, T., \& Heasman, M. (2004). Food wars: The global battle for mouths, minds and markets. London, U.K.: Earthscan. 
Leeuwis, C. (2004). Communication for rural innovation: Rethinking agricultural extension. Oxford, U.K.: Blackwell Publishing.

Mathison, S. (1988). Why triangulate? Educational Researcher, 17(2), 13-17. http://dx.doi.org/10.3102/0013189X017002013

Marsden, T. (2003). The condition of rural sustainability. Assen, the Netherlands: Van Gorcum.

Marsden, T., \& Smith, E. (2004). Ecological entrepreneurship: Sustainable development in local communities through quality food production and local branding. Geoforum, 36, 440-451. http://dx.doi.org/10.1016/j.geoforum.2004.07.008

Milone, P. (2009). Agriculture in transition: A neoinstitutional analysis. Assen, the Netherlands: Van Gorcum.

Rammel, C., Stagl, S., \& Wilfing, H. (2007). Managing complex adaptive systems - A co-evolutionary perspective on natural resource management. Ecological Economics, 63, 9-21. http://dx.doi.org/10.1016/j.ecolecon.2006.12.014

Rip, A., \& Kemp, R. (1998). Technological change. In S. Rayner \& E. L. Malone (Eds.), Human choice and climate change (Vol. 2, pp. 327-399). Colombus, Ohio: Battelle Prêss.

Roep, D. (2000). Vernieuwend werken: Sporen van vermogen en onvermogen: Een sociomateriële studie over vernieuwing in de landbouw nitgewerkt voor de westelijke veenweidegebieden (Doctoral dissertation). Wageningen University, Wageningen, the Netherlands.

Rotmans, J., Kemp, R., van Asselt, M., Geels, F., Verbong, G., \& Molendijk, K. (2000). Transitions and transition management: The case of low-emission energy supply. Maastricht, the Netherlands: International Centre for Integrative Studies (ICIS).

Schot, J., \& Geels, F. W. (2008). Strategic niche management and sustainable innovation journeys: Theory, findings, research agenda, and policy. Technology Analysis \& Strategic Management, 20(5), 537-554. http://dx.doi.org/10.1080/09537320802292651

Sevilla Guzmán, E., \& Martínez Alier, J. (2006). New rural social movements and agroecology. In P. Cloke, T. Marsden, \& P. H. Mooney (Eds.), Handbook of rural studies (pp. 472-483). London: Sage.
Sonnino, R., \& Marsden, T. (2006). Beyond the divide: Rethinking relationships between alternative and conventional food networks in Europe. Journal of Economic Geography, 6(2), 181-199. http://dx.doi.org/10.1093/jeg/lbi006

Soto, D. (2006). Historia dunha agricultura sustentábel: Transformacións productivas na agricultura galega contemporánea (Colección EIDOS, n. 4). Santiago: Consellería de Medio Rural da Xunta de Galicia.

Spradley, J. P. (1979). The ethnographic interview. New York: Holt Rhinehart Winston.

Stagl, S. (2007). Theoretical foundations of learning processes for sustainable development. International Journal of Sustainable Development \& World Ecology, 14, 52-62.

Stake, R. E. (2000). Case studies. In N. K. Denzin \& Y. $\mathrm{S}$. Lincoln (Eds.), Handbook of qualitative research (pp. 435-454). London: Sage.

Svendsen, G. L. H. (2006). Studying social capital in situ: A qualitative approach. Theory and Society, 35, 39-70. http://dx.doi.org/10.1007/s11186-006-6780-3

Swagemakers, P. (2002). Verschil maken: Novelty-productie en de contouren van een streekcooperatie. Wageningen: Circle for Rural European Studies/Leerstoelgroep Rurale Sociologie.

Swagemakers, P. (2008). Ecologisch kapitaal: Over het belang van aanpassingsvermogen, flexibiliteit en oordeelkundigheid (Doctoral dissertation). Wageningen University, Wageningen, the Netherlands.

Toledo, V. M. (1990). The ecological rationality of peasant production. In M. A. Altieri \& S. B. Hecht (Eds.), Agroecology and small farm development (pp. 5360). Boca Raton, Florida: CRC Press.

United Nations. (2010, December 20). Report submitted by the Special Rapporteur on the right to food, Olivier De Schutter (Report A/HRC/16/49). New York: Author.

van den Ende, J. (1999). Technological transformations in history: How the computer regime grew out of existing computing regimes. Research Policy, 28, 833-851. http://dx.doi.org/10.1016/S00487333(99)00027-X

van der Ploeg, J. D. (1997). On rurality, rural development and rural sociology. In H. de Haan, and \& N. Long (Eds.), Images and realities of rural life. $W$ ageningen perspectives on rural transformations (pp. 3973). Assen, the Netherlands: Van Gorcum. 
van der Ploeg, J. D. (2000). Revitalizing agriculture: Farming economically as starting ground for rural development. Sociologia Ruralis, 40(4), 497-511. http://dx.doi.org/10.1111/1467-9523.00163

van der Ploeg, J. D. (2003). The virtual farmer. Assen, the Netherlands: Van Gorcum.

van der Ploeg, J. D. (2006). Agricultural production in crisis. In P. Cloke, T. Marsden, \& P. H. Mooney (Eds.), Handbook of rural studies (pp. 258-278). London, U.K.: Sage.

van der Ploeg, J. D. (2008). The new peasantries: Struggles for autonomy and sustainability in an era of empire and globalization. London, U.K.: Earth Scan.

van der Ploeg, J. D. (2010). The food crisis, industrialized farming and the imperial regime. Journal of Agrarian Change, 10(1), 98-106. http://dx.doi.org/10.1111/j.14710366.2009.00251.x

van der Ploeg, J. D., van Broekhuizen, R., Brunori, G., Sonnino, R., Knickel, K., Tisenkopfs, T., \& Oostindie, H. (2009). Towards a framework for understanding regional rural development. In J. D. van der Ploeg \& T. Marsden (Eds.), Unfolding webs: The dynamics of regional rural development (pp. 1-28). Assen, the Netherlands: Van Gorcum. van der Ploeg, J. D., Bouma, J., Rip, A., Rijkenberg, F. H. J., Ventura, F., \& Wiskerke, J. S. C. (2004). On regimes, novelties, niches and co-production. In J.S.C. Wiskerke \& J.D. van der Ploeg (Eds.), Seeds of transition: Essays on novelty production, niches and regimes in agriculture (pp. 1-30). Assen, the Netherlands: Van Gorcum.

van der Ploeg, J. D., Verschuren, P., Verhoeven, F., \& Pepels, J. (2006). Dealing with novelties: A grassland experiment reconsidered. Journal of Environmental Policy and Planning 8(3), 199-218. http://dx.doi.org/10.1080/15239080600915568 van Kessel, J. (1990). Herwaarderen om te herleven: Productieritueel en technologisch betoog bij Andesvolkeren. Derde Wereld (1/2), 77-97. van Lente, H. (1993). Promising technologies: The dynamics of expectations in technological developments (Doctoral dissertation). University of Twente, Enschede, the Netherlands.

Ventura, F., \& Milone, P. (2004). Novelties as redefinitions of farm boundaries. In J. S. C. Wiskerke \& J. D. van der Ploeg (Eds.), Seeds of transition: Essays on novelty production, niches and regimes in agriculture (pp. 57-92). Assen, the Netherlands: Van Gorcum.

Verschuren, P., \& Doodewaard, H. (1999). Designing a research project. Utrecht, the Netherlands: Lemma.

Warde, A. (2005). Consumption and theories of practice. Journal of Consumer Culture, 5(2), 131-153. http://dx.doi.org/10.1177/1469540505053090

Wikipedia. (2011). Polder. Retrieved 24 January 2012 from http://en.wikipedia.org/wiki/Polder

Wiskerke, J. S. C. (2009). On places lost and places regained: Reflections on the alternative food geography and sustainable regional development. International Planning Studies, 14(4), 369-387. http://dx.doi.org/10.1080/13563471003642803

Wiskerke, J. S. C. (2007). Robust regions: Dynamics, coherence and diversity in the metropolitan landscape. Inaugural lecture at Wageningen University, Wageningen, the Netherlands.

Wiskerke, J. S. C., van Huylenbroeck, G., \& Kirwan, J. (In press). Sustaining food supply chains: Grounded perspectives on the dynamics and impact of new modes of food provision. London, U.K.: Ashgate Publishers.

Wiskerke, J. S. C., \& van der Ploeg, J. D. (2004). Seeds of transition: Essays on novelty production, niches and regimes in agriculture. Assen, the Netherlands: Van Gorcum.

Yin, R. K. (1984). Case study research: Design and methods. London: Sage. 
Journal of Agriculture, Food Systems, and Community Development ISSN: 2152-0801 online www.AgDevJournal.com 